Assisted reproductive technologies, such as in vitro fertilization, have made their way to the Middle Eastern nation states. However, in the Sunni-dominant countries, third-party donation of sperm, eggs, embryos, and uteruses (as in surrogacy) is banned, leading some Sunni Muslim couples to travel to Iran and Lebanon, where Shia Muslim clergy have allowed donor technologies.

\title{
Islam, assisted reproductive technologies, and the Middle Eastern state
}

Marcia C. Inhorn, PhD, MPH, born in 1957, is Professor in the Department of Anthropology, School of Public Health, Program in Women's Studies, and Department of Obstetrics and Gynecology at the University of Michigan, Ann Arbor, where she also directed (2003-2006) the Center for Middle Eastern and North African Studies. She is the founding editor of Journal of Middle East Women's Studies, the official journal of the Association for Middle East Women's Studies, Middle East Studies Association. 
TEXT: Marcia C. Inhorn

IN THE NEW MiLlennium, the Middle Eastern assisted reproductive technology (ART) industry is flourishing, with hundreds of in vitro fertilization (IVF) clinics in countries ranging from the small Arab Gulf states to the larger but less prosperous nations of

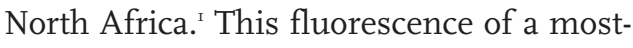
ly private Middle Eastern ART industry is not surprising: Islam encourages the use of science and medicine as solutions to human suffering and is a religion that can be described as "pronatalist", encouraging the growth of an Islamic "multitude". ${ }^{2}$

Yet, relatively little is known about Islam and technoscience, if technoscience is defined broadly as the interconnectedness between science and technology. As noted by Lotfalian in his recent monograph on Islam, Technoscientific Identities, and the Culture of Curiosity, ${ }^{3}$ there is a glaring lacu- na in the literature on science and technology in a cross-cultural perspective, particularly from the Muslim world. This dearth of relevant scholarship clearly applies to the cross-cultural study of ARTs and thirdparty donation. For example, in the seminal volume on Third Party Assisted Conception Across Cultures: Social, Legal and Ethical Perspectives, ${ }^{4}$ not a single Muslim society is represented among the thirteen country case studies.

Clearly, the time has come to examine the globalization of ARTs to diverse contexts in the Muslim world, particularly given the rapid development and evolution of these technologies over time. As I will argue in this article, assisted reproduction in the Muslim Middle East bespeaks a complex "global assemblage"s of technologies, gametes, legislation, religion, money, and ideas involving the pursuit of conception. That infertile Muslim couples are willing to participate in this world bespeaks the love, commitment, and ardent desire for children that characterize most ART-seeking couples in the Middle East, but that are rarely emphasized in the Western media discourses about purported Middle Eastern violence, religious fanaticism, and the cruelty of Muslim men to women. As I have argued elsewhere, ${ }^{6}$ the love between infertile couples is fueling the ART industry in the Middle East. It is also causing some Muslim couples to venture across deepening Sunni-Shia religious and political divides in search of human gametes (i.e. donor sperm, oocytes, and embryos), even at an historical moment when tensions between these two Muslim communities are at an all-time high. ${ }^{7}$

In the Muslim Middle East, practices of assisted conception are now tied to varying 
sectarian religious attitudes toward gamete donation, codified in authoritative Islamic fatwa declarations and upheld by Middle Eastern states, which tend to have weak regulatory structures. Indeed, religion regulates ART practice much more clearly and effectively than state mandates in the form of laws or other regulatory mechanisms, which are either minimal or nonexistent. This "strong religion/weak state" reality has in recent years led in recent years to two clear patterns of ART practice, which follow the growing Sunni/Shia sectarian divide in this part of the world. As we shall see, all Sunni-dominant countries in the Middle East ban third-party gamete donation, while gamete donation is now practiced in at least two Shia-majority nations.

This article will focus on two of each Egypt and the United Arab Emirates, both Sunni-dominant countries, and Iran and Lebanon, both Shia-dominant countries where I have conducted extensive field research on ARTs with hundreds of Muslim couples. ${ }^{8}$ The interaction between religion and the state will be highlighted for each country. To do so requires examining fatwas, or non-legally binding but authoritative Islamic religious decrees, as well as the subsequent ethical and legal rulings that are being issued by some Middle Eastern states to enforce or, in some cases, overturn these fatwa rulings. ${ }^{9}$ Understanding the rapidly evolving religion-state nexus surrounding ARTs in the Muslim world is imperative. Perhaps unlike any other major region of the world, Islamically imposed religious restrictions guide clinical practice throughout the Middle Eastern region, with relatively little state legislation or intervention. This "strong religion/weak state" scenario effects affects not only what clinics are able to offer to patients, but also what patients are able to accept as morally permissible in their personal treatment quests.

Indeed, a key question is how the religion-state nexus actually plays out in the "making of Muslim babies" within Middle Eastern IVF centers. ${ }^{\text {IO }}$ Harvard medical anthropologist Arthur Kleinman has coined the term "local moral worlds" to describe "the commitments of social participants in a local world about what is at stake in everyday experience." ${ }^{\text {II }}$ In the Middle East, understanding local moral worlds involves asking what Muslim ART-seekers think about IVF and specifically donor technologies. How do disparate Sunni-Shia stances toward gamete donation influence the "local moral worlds" of infertile Muslim couples, desperate to produce a child? When faced with the need for donor gametes to overcome infertility, what do Muslim IVF patients, whether Sunni and or Shia, actually do? Understanding local moral attitudes toward science, technology, medicine, and religion in the Middle East requires ethnographic engagement with reproductive actors themselves, including those who seek human gametes across national and sectarian divides.

\section{ARTs in Sunni Islam}

It is important to begin in the Sunni Muslim world, where the earliest fatwas on ART practice emerged and where the first clinics opened in the Sunni strongholds of Egypt, Saudi Arabia, and Jordan. The Grand Sheikh of Egypt's famed religious university, Al Azhar, issued the first fatwa on medically assisted reproduction on March 23, I980. This initial fatwa - issued only two years after the first IVF birth in England, 
but a full six years before the opening of Egypt's first IVF center-has proved to be truly authoritative and enduring in all its main points. In fact, the basic tenets of the original Al-Azhar fatwa on IVF have been upheld by other fatwas issued since I980 and have achieved wide acceptance throughout the Sunni Muslim world.

The Sunni Islamic position on assisted reproduction clearly permits in vitro fertilization, using eggs from the wife with the sperm of her husband and the transfer of the fertilized embryos back to the uterus of the same wife. However, since marriage is a contract between the wife and husband during the span of their marriage, no third party should intrude into the marital functions of sex and procreation. This means that a third party donor is not acceptable, whether he or she is providing sperm, eggs, embryos, or a uterus (as in surrogacy). As noted by Islamic legal scholar Ebrahim Moosa:

"In terms of ethics, Muslim authorities consider the transmission of reproductive material between persons who are not legally married to be a major violation of Islamic law. This sensitivity stems from the fact that Islamic law has a strict taboo on sexual relations outside wedlock (zina). The taboo is designed to protect paternity (i.e., family), which is designated as one of the five goals of Islamic law, the others being the protection of religion, life, property, and reason. ${ }^{{ }_{12}}$

As a result, at the ninth Islamic law and medicine conference, held under the auspices of the Kuwait-based Islamic Organization for Medical Sciences (IOMS) in Casablanca, Morocco, in I997, a landmark five-point declaration included recommen- dations to prevent human cloning and to prohibit all situations in which a third party invades a marital relationship through donation of reproductive material. ${ }^{\mathrm{I3}}$ Such a ban on third-party gamete donation is effectively in place in the Sunni world, which represents approximately 90 percent of the world's I.3 billion Muslims. ${ }^{\text {.4 }}$

But to what degree are these Sunni fatwa declarations actually followed by physicians in the Muslim world? A I997 global survey

The donor child can only inherit from the sperm or egg donor, as the parents are considered to be adoptive parents.

of sperm donation among assisted reproductive technology centers in 62 countries provides some indication of the degree of convergence between official discourse and actual practice. ${ }^{15}$ In all of the Sunni-dominant Muslim countries surveyed-including the Middle Eastern countries of Egypt, Kuwait, Jordan, Morocco, Qatar, and Turkey, as well as a number of non-Middle Eastern Muslim countries including Indonesia, Malaysia, and Pakistan - sperm donation in IVF and all other forms of gamete donation were strictly prohibited. As the authors of this global survey note, "In many Islamic countries, where the laws of Islam are the laws of the state, donation of sperm was not practiced. Artificial insemination by donor AID is considered adultery and leads to confusion regarding the lines of genealogy, whose purity is of prime importance in Islam." ${ }^{{ }^{6} 6}$

The statement "the laws of Islam are the laws of the state" bears further investigation, for it is not, technically, accurate. 


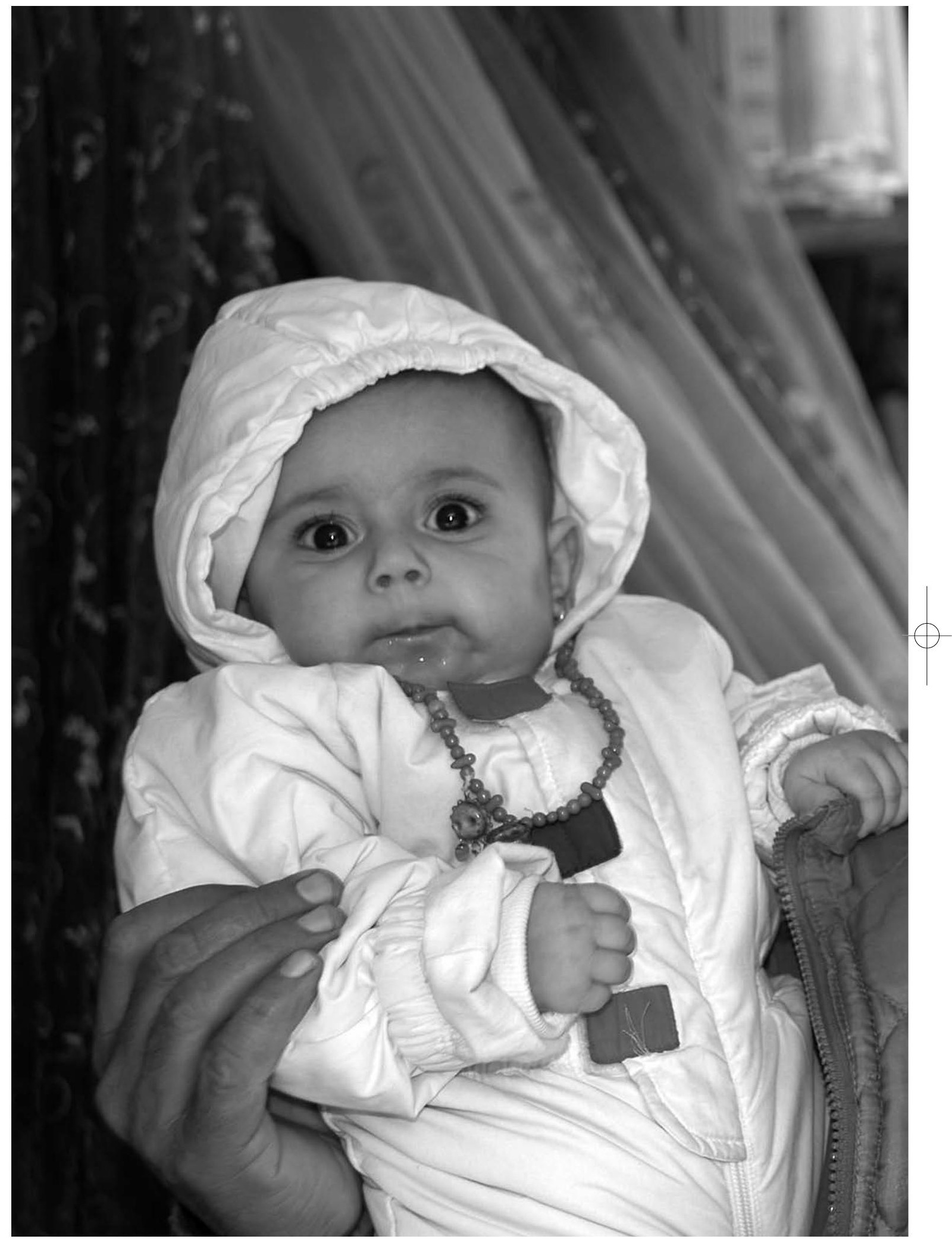




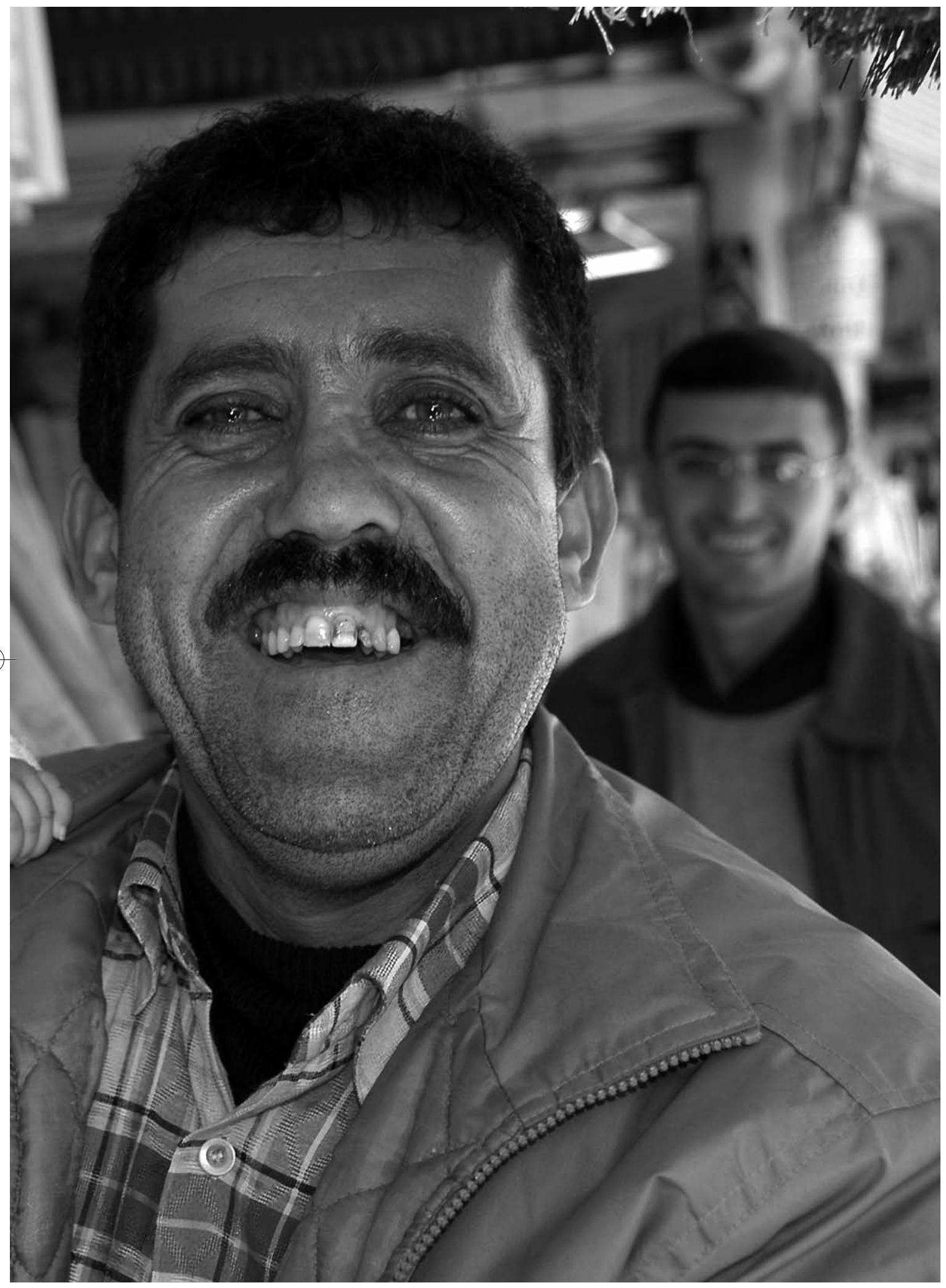


Islamic law, called sharia, governs family law (i.e., personal status law) in most Middle Eastern societies. However, separate civil legal codes, often imposed during periods of French and British colonial rule, govern most other areas of law throughout the region. ${ }^{\text {17 }}$ ARTs come under the aegis of Islamic family law, given that ARTs are used to produce offspring for infertile couples. The association of ARTs with Islamic sharia has given religion outstanding power to dictate the scope and contours of

\section{Egg donation is allowed,} as long as the husband marries the egg donor temporarily.

clinical practice in the Muslim world, effectively weakening state intervention or civil law in this area.

Egypt is case in point. Over the past 20 years, Egypt has supported a thriving IVF sector, with approximately 50 IVF clinics. Five of these clinics are located in government hospitals and receive some state funding to offset expenses for the infertile poor. ${ }^{18}$ However, as in most Middle Eastern countries, Egypt's IVF sector is highly privatized and exists beyond the official gaze of the state. Opening an IVF clinic requires licensure by the Egyptian Ministry of Health, based on guidelines set forth by the Egyptian Medical Syndicate. However, the Egyptian Medical Syndicate has based its bioethical guidelines for clinic operation upon the early fatwa issued by Al Azhar, as well as the subsequent recommendations of the I99I, I997, and 2000 conferences on ARTs organized by Al Azhar's International Islamic Center for Population Stud- ies and Research and endorsed by the $\mathrm{Al}$ Azhar clergy. ${ }^{19}$

Prof. Gamal Serour, the director of the center at Al Azhar, laments the comparable lack of Egyptian state involvement in this process. "Unfortunately, there have not been any attempts to legislate IVF in Egypt," he writes. "The state controls the practice of IVF through licensing these centers. Centers have to abide by the guidelines laid [out] by the medical syndicate concerning premises, personnel, equipment, facilities, sterilization, etc. Every center must obtain approval of the medical syndicate followed by a license from $\mathrm{MOH}$ [Ministry of Health] before they start their programs." "However," he adds, "the "regulations environment in Egypt is poor. It stops at the phase of issuing a license. There is no regulatory body which supervises or inspects the work done; neither is there an obligatory registry for compiling data. Of course, inspection occurs whenever a catastrophe occurs. ${ }^{{ }^{\circ \circ}}$ Concurring completely with this assessment, Prof. Mohamed Yehia, one of Prof. Serour's IVF colleagues at neighboring Ain Shams University in Cairo, describes the regulatory environment in Egypt as "very loose and mainly governed by the doctor-patient relationship." tors and clinics operate with little government interference does not mean that "anything goes" in either Egypt or other Sunni Muslim countries. Indeed, what is quite remarkable is the degree to which the fatwa banning third-party donation is actually followed by both practitioners and patients in the Sunni Muslim world. Sunni Muslim physicians in the Middle East appear loathe to offeroffering gamete donation to their patients. According to them, clinics in the 
Sunni-dominant countries simply do not use donor technologies, which violate the sharia guidelines. Instead, if couples with recalcitrant infertility ask about gamete donation, they are either discouraged by their physicians from pursuing it further or are referred out of the country, primarily to Europe.

Indeed, most Sunni Muslim IVF patients would never dream of "doing donor", and desire their clinical care from a Sunni Muslim IVF physician who shares this conviction. In the hundreds of interviews that I have conducted with Sunni IVF patients in disparate Middle Eastern settings, the vast majority agree completely with the religious prohibitions on gamete donation, arguing that gamete donation: (I) is tantamount to adultery, by virtue of introducing a third party into the sacred dyad of husband and wife; (2) creates the potential for future half-sibling incest, if the offspring of the same anonymous donor meet and marry; and (3) confuses kinship, paternity, descent, and inheritance in the emphatically patrilineal societies of the Muslim Middle East. According to them, preserving the "origins" of each child meaning its relationship to a known biological mother and father - is considered not only an ideal in Islam, but a moral imperative.The problem with third-party donation, therefore, is that it destroys a child's nasab, or lineage, which is considered immoral in addition to being psychologically devastating. A donor child could only be viewed as an ibn haram, literally "son of sin". The child will be deemed illegitimate and stigmatized even in the eyes of its own parents, who will therefore lack the appropriate parental sentiments. ${ }^{22}$

This firm conviction that parenthood of a "donor child" is an impossibility is clearly linked to the legal and cultural prohibitions against adoption throughout the Sunni Muslim world. ${ }^{23}$ The original AlAzhar fatwa prohibiting third-party gamete donation also prohibits adoption of orphans, considering both of them unallowable. ${ }^{24}$ As a result, few Sunni Muslim IVF patients will contemplate adopting an orphan, stating with conviction that it is "against the religion." According to Sunni Muslim men, an adopted child, like a donor child, "won't be my son." 25

Given this local moral world, most Sunni IVF patients are extremely concerned about making their test-tube babies in a morally correct fashion. To that end, seeking out a trustworthy Sunni Muslim IVF practitioner is a concern for many patients. Interestingly, in the United Arab Emirates (UAE), the "global hub" of the Middle East (i.e., less than one-quarter of the total population of 4 million are Emirati nationals), a controversial draft law to govern UAE IVF centers includes a clause stating that every IVF center must have at least two Muslim practitioners, one an IVF specialist and one a laboratory technician, in order to be licensed. Attempting to reflect the UAE's multicultural population, two government ministers present at the legislative hearing argued that "science and medicine have no religion," and that "the UAE constitution does not discriminate against any citizen on religious grounds." Nonetheless, the majority of those present at the July 3, 2007 hearing of the voted to include the controversial clause in the draft law. ${ }^{26}$

\section{ARTs in Shia Islam}

Having said all of this, it is very important to point out how things have changed for 
Shia Muslims since the beginning of the new millennium. Until recently, most Shia religious authorities have supported the majority Sunni view: namely, they agree that third-party donation should be strictly prohibited. However, in the late I990s, the Supreme Leader of the Islamic Republic of Iran, Ayatollah Ali Hussein Khamenei, the hand-picked successor to Iran's Ayatollah Khomeini, issued a fatwa effectively permitting donor technologies to be used under certain conditions. ${ }^{27}$ With regard to both egg and sperm donation, Ayatollah Khamenei stated that both the donor and the infertile parents must abide by the religious codes regarding parenting. However, the donor child can only inherit from the sperm or egg donor, as the infertile parents are considered to be like "adoptive" parents.

However, the situation for Shia Muslims is actually much more complicated than this. Because the Shia favor a form of individual religious reasoning known as ijtihad, various Shia religious authorities have come to their own conclusions about sperm and egg donation. There are major disagreements about:

(I) whether gamete donation without bodily contact truly constitutes zina, or adultery;

(2) whether donation is permissible at all if the donors are anonymous;

(3) whether the husband of an infertile woman needs to do a temporary marriage mut' $a$ with the egg donor, then release her from the marriage immediately after the embryo transfer, in order to avoid zina, or adultery (such mut'a marriages are condoned in Shia, but condemned in Sunni Islam);

(4) whether a Shia Muslim woman mar- ried to an infertile man can do a mut'a marriage with a sperm donor (an illegal state of polyandry), or whether she should temporarily divorce her infertile husband, remarrying him after accepting sperm from a donor.

In theory, only widowed or otherwise single women - who are not currently married - should be able to accept donor sperm, in order to avoid the implications of zina, or adultery. However, in all of the Muslim countries, single motherhood of a donor child is unlikely to be socially acceptable.

Indeed, in a most interesting legislative turn of events, the Iranian state has issued a law making sperm donation officially illegal - thereby effectively overruling Ayatollah Khamenei's fatwa-based permission of sperm donation. Namely, a law on embryo donation passed in 2003 in the Iranian parliament (Majlis) and approved by the Guardian Council (i.e., a religious "watchdog" body that endorses every bill before it becomes law) has restricted gamete donation to married persons. Even though the law is brief (less than one page), it states clearly and succinctly who can and cannot donate and receive gametes. Egg donation is allowed, as long as the husband marries the egg donor temporarily - ensuring that all three parties are married. Sperm donation, on the other hand, is legally forbidden, because a sperm donor cannot temporarily marry an already married woman whose husband is infertile. Quite interestingly, however, embryo donation - which involves both sperm and egg from another couple - is allowed in order to overcome both male and female infertility. Because an embryo comes from a married couple and is given to another married couple, it is 
considered halal, or religiously permissible. $^{28}$

Some Iranian clergy and physicians are presently advocating for future laws permitting all forms of donation as well as surrogacy. Once passed into law, gamete donation and surrogacy will be difficult to stop. Meanwhile, in the absence of formal legislation, some IVF physicians in Tehran - as

\section{mom \\ Ironically, those most likely to recieve "American eggs" are conservative Shia couples.}

well as in the Shia-dominant country of Lebanon, which is closely following the Iranian lead - are using the legal vacuum and original "permissive" fatwa of Ayatollah Khameanei to practice all forms of gamete donation and surrogacy among their desperate infertile patients. Lebanon, a multi-sectarian country where Shia comprise the majority of Muslims, has attempted to legislate against third party procedures of all kinds, and to limit access to ARTs to married couples. However, because of the strong Shia presence in that country, and the inability to achieve consensus among Lebanon's seventeen other confessional communities, the legislative process has been suspended indefinitely. Indeed, with its long history of sectarianism and religious infighting, Lebanon represents a case par excellence of "strong religion/weak state”. In practice, ART decisions are left largely to the better judgment of IVF doctors and patients, based on their own religious and bioethical convictions.

Given these moral and legal ambigui- ties, at least some Shia Muslim couples are beginning to receive donor gametes, as well as donating their gametes to other infertile couples. Since the new millennium, donor gametes are now being donated and procured by infertile couples in IVF clinics in Shia-majority Iran and Lebanon, the only two countries in the Muslim world that appear to allow this practice at the present time. For infertile Shia couples who accept the idea of donation, the introduction of donor technologies has been described as a "marriage savior", helping to avoid the "marital and psychological disputes" that may arise if the couple's case is otherwise untreatable.

Who are the sources of these donor gametes? In the Lebanese IVF clinics in which I worked, some of the donors were other IVF patients (mostly Shia Muslims who accept the idea of donation), some were friends or relatives (including eggdonor sisters), and some were anonymous donors, who provided their ova for a fee. In at least one clinic catering to a largely conservative Shia clientele, some of these donors were young non-Muslim, American women, who travel from the Midwest to Lebanon for extra payment in order to anonymously donate their eggs to infertile Lebanese couples. Ironically, those most likely to receive these "American eggs" are conservative Shia couples, who accept the idea of donation because they follow the teachings of Ayatollah Khameanei in Iran. In Lebanon, such couples are generally members of or sympathizers with Lebanon's Hizbullah political party, which is officially described by the U.S. administration as a terrorist organization!

Furthermore, quite interestingly, in multi-sectarian Lebanon, the recipients of 
these donor eggs are not necessarily only Shia Muslim couples. Some Sunni Muslim patients from Lebanon and from other Middle Eastern Muslim countries such as Egypt and Syria are quietly slipping across transnational borders to "save their marriages" through the use of donor gametes, thereby secretly "going against" the dictates of Sunni Muslim orthodoxy. That such reproductive tourism is done in secrecy usually under the guise of a "holiday in Beirut" - is quite important, given the moral condemnation of gamete donation in the Sunni Muslim countries. Although such Sunni Muslim gamete seekers may have made peace with their own moral decisions to use donor technologies, they often remain extremely concerned about maintaining anonymity and confidentiality, in order to avoid moral censure of themselves and their future donor offspring.

\section{Conclusion}

In short, the arrival of donor technologies in both Lebanon and Iran - the only two Middle Eastern countries to offer these services at the present time - has led to a brave new world of reproductive possibility never imagined when these technologies were first introduced there more than twenty years ago. These technologies have engendered significant medical transnationalism and reproductive tourism; mixing of gametes across national, ethnic, racial, and religious lines; and the birth of thousands of IVF and donor babies to devout infertile Muslim couples. For their part, at least some infertile Muslim couples, both Shia and Sunni, have begun to reconsider traditional notions of biological kinship, even if "social parenthood" of a donor child is still not widely embraced in the Middle Eastern region. ${ }^{30}$ Nonetheless, because donor technologies are now widely available in both Iran and Lebanon, the power of the Sunni Muslim ban on thirdparty donation is being weakened across the region, with some infertile Sunni Muslim couples reconsidering their own antidonation moral stances. As a result of these social processes, Shia gametes are finding their ways into Sunni bodies, despite the regional antagonisms between these two warring religious sects. Indeed, in the new millennium, the case of assisted conception and gamete donation provides compelling material for the study of Islamic technoscience in practice - a study that is ripe for anthropological investigation as these technologies make their way to diverse Muslim societies around the globe.

$$
\cdot f \cdot
$$

I Inhorn, Marcia C.: Local Babies, Global Science: Gender, Religion, and In Vitro Fertilization in Egypt. Routledge New York 2003.

2 Musallam, B. F. : Sex and Society in Islam: Birth Control Before the Nineteenth Century. Cambridge University Press, Cambridge, United Kingdom I986.

3 Ibid.

4 Blyth, Eric, and Landau, Ruth, eds.: Third Party Assisted Conception Across Cultures: Social, Legal and Ethical Perspectives. Jessica Kingsley, London 2004.

5 Ong, Aihwa, and Collier, Stephen J., eds. Global Assemblages: Technology, Politics, and Ethics as Anthropological Problems. Blackwell, Malden, Massachusetts 2005.

6 Inhorn, Marcia C.: “Loving Your Infertile Muslim Spouse: Notes on the Globalization of IVF and Its Romantic Commitments in Sunni Egypt and Shia Lebanon." In Love and Globalization: Transformations of Intimacy in the Contemporary World, eds. Mark B. Padilla, Jennifer S. Hirsch, Miguel Munoz-Laboy, Robert Sember, and Richard G. Parker, pp. I39-I60. Vanderbilt University Press, Nashville, TN 2007.

7 Nasr, Vali: The Shia Revival: How Conflicts within Islam will Shape the Future. W.W. Norton \& Co., New York 2006.

8 Since I988, I have undertaken long-term field research in four Middle Eastern societies-Egypt (1988-89, I996), Lebanon (2003), "Arab Detroit” (2003-2005, 2007-2009), 
and United Arab Emirates (2007)-with additional research-related trips to Syria (2002-2003), Cyprus (2003), Lebanon (2006), Iran (2006), Egypt (2007), and Qatar (2007). I have conducted in-depth, ethnographic interviews with nearly 600 patient couples and numerous IVF physicians and clinic staff members, the vast majority of whom are Muslim. For a more comprehensive discussion of my research methods and fieldwork experiences, see Inhorn, Marcia C.: "Privacy, Privatization, and the Politics of Patronage: Ethnographic Challenges to Penetrating the Secret World of Middle Eastern, HospitalBased In Vitro Fertilization" in Social Science and Medicine, vol. 59, 2004. My field research has been generously supported by multiple grants from the U.S. National Science Foundation and the U.S. Department of Education's Fulbright-Hays Faculty Research Abroad program. I am also grateful to all of the Middle Eastern IVF patients and staff who have made my research possible over the years. Alf alf shukran!

9 Tremayne, Soraya: "Law, Ethics, and Donor Technologies in Shia Iran.” In Assisting Reproduction, Testing Genes: Global Encounters with New Biotechnologies, eds. Daphna Birenbaum-Carmeli and Marcia C. Inhorn. Berghahn Books, New York, in press.

Io Inhorn, Marcia C.: "Making Muslim Babies: IVF and Gamete Donation in Sunni versu Shi'a Islam " in Culture, Medicine and Psychiatry vol. 30:, 2006.

II Kleinman, Arthur: Writing at the Margin: Discourse Between Anthropology and Medicine. University of California Press, Berkeley I995.

I2 Moosa, Ebrahim: "Human Cloning in Muslim Ethics" in Voices Across Boundaries, Fall, 2003.

I3 Ibid.

I4 Serour, G. I., and Dickens, B.M.: "Assisted Reproduction Developments in the Islamic World" in International Journal of Gynecology \& Obstetrics, vol. 74, 2001.

I5 Meirow, D., and Schenker, J.G.: "The Current Status of Sperm Donation in Assisted Reproduction Technology: Ethical and Legal Considerations" in Journal of Assisted Reproduction and Genetics, vol. I4, I997.

I6 Ibid.

I7 The notable exceptions are Iran, Sudan, and Somalia, where Islamic law has been imposed on all citizens (including non-Muslims) in matters other than family law.

I8 Prof. Mohamed Yehia, personal communication, July 29 2007

I9 Prof. Gamal I. Serour, personal communication, July 30 , 2007

20 Ibid.

2I Prof. Mohamed Yehia, personal communication, July 29, 2007

22 Inhorn, Marcia C.:“'He Won’t Be My Son': Middle Eastern Muslim Men's Discourses of Adoption and Gamete Donation" in Medical Anthropology Quarterly, vol. 20, 2006.
23 Sonbol, Amira el Azhary: "Adoption in Islamic Society: A Historical Survey." in Children in the Muslim Middle East, ed. Elizabeth Warnock Fernea, pp. 45-67. University of Texas Press, Austin I995.

24 Inhorn, Marcia C.: "Fatwas and ARTs: IVF and Gamete Donation in Sunni v. Shi'a Islam" in Journal of Gender, Race \& Justice, vol. 9, 2005.

25 Inhorn, Marcia C.:"'He Won't Be My Son': Middle Eastern Muslim Men's Discourses of Adoption and Gamete Donation" in Medical Anthropology Quarterly, vol. 20, 2006.

26 Salama, Samir: "FNC in Heated Debate on Bill Regulating IVF Centres" in The Gulf News, Dubai, 4 July 2007.

27 For discussions of ARTs in Iran, see Abbasi-Shavazi, Mohammad Jalal, Inhorn, Marcia C., Razeghi-Nasrabad, Hajieh Bibi, and Toloo, Ghasem. "The Iranian ART Revolution: Infertility, Assisted Reproductive Technologies, and Third-Party Donation in the Islamic Republic of Iran" in JMEWS (Journal of Middle East Women's Studies, vol. 4, 2008 in press; Clarke, Morgan: Islam and New Kinship: Reproductive Technology, Anthropology, and the Shari'ah in Lebanon. Berghahn Books, New York 2008 in press; Clarke, Morgan: "Children of the Revolution: 'Ali Khamene'i's 'Liberal' Views on in vitro Fertilization" in British Journal of Middle Eastern Studies, vol. 34, 2007; Clarke, Morgan: "Shiite Perspectives on Kinship and New Reproductive Technologies” in ISIM Newsletter, vol. I7, 2006; Garmaroudi, Shirin: Kinship Intimacy in the Age of Assisted Conception: An Ethnographic Account of the Assisted Reproduction Technologies in Iran. Master's Thesis, Institute of Social Anthropology, University of Bern, Switzerland, 2008; Tremayne, Soraya: "Not All Muslims are Luddites" in Anthropology Today, vol. 22, 2006; Tremayne, Soraya: "Law, Ethics, and Donor Technologies in Shia Iran." in Assisting Reproduction, Testing Genes: Global Encounters with New Biotechnologies, eds. Daphna Birenbaum-Carmeli and Marcia C. Inhorn. Berghahn Books, New York, in press.

28 Tremayne 2006, 2008

29 Ibid.; Garmaroudi, Shirin: Kinship Intimacy in the Age of Assisted Conception: An Ethnographic Account of the Assisted Reproduction Technologies in Iran. Master's Thesis, Institute of Social Anthropology, University of Bern.

30 Inhorn, Marcia C.:“'He Won't Be My Son': Middle Eastern Muslim Men's Discourses of Adoption and Gamete Donation" in Medical Anthropology Quarterly, vol. 20, 2006. 